\title{
PLAGL2 Gene
}

National Cancer Institute

\section{Source}

National Cancer Institute. PLAGL2 Gene. NCI Thesaurus. Code C91257.

This gene is involved in DNA binding and transcriptional regulation. 